\author{
๑) О. В. Багатько \\ Медичний центр «Мати та дитина», Київ
}

\title{
ЯКІСТЬ ЖИТТЯ ПАЦІЕНТОК ІЗ ТРУБНО-ПЕРИТОНЕАЛЬНИМ БЕЗПЛІДДЯМ У ПРОЦЕСІ ЛІКУВАННЯ
}

Мета дослідження - вивчити якість життя жінок репродуктивного віку з трубно-перитонеальним безпліддям у процесі КСО

Матеріали та методи. Для вирішення поставленої мети проведено обстеження 250 жінок репродуктивного віку 3 трубно-перитонеальним безпліддям, які були розподілені на дві групи й відрізнялися лише використаним препаратом для КСО. Оцінку якості життя виконували з використанням опитувача «SF-36» та міжнародної анкети FertiQol (2008).

Результати дослідження та їх обговорення. Оцінка якості життя за допомогою опитувача «SF-36» показала, що до початку лікування безпліддя в жінок із трубно-перитонеальним безпліддям вона була досить низькою, в першу чергу, за рахунок психологічного компонента здоров'я. Вивчення якості життя при використанні опитувача FertiQoL показала, що найбільше страждала якість життя в жінок із безпліддям у соціальній сорері. Повторне опитування пацієнток із безпліддям проводилося на 5 день після ембріотранссреру. У фрізичному компоненті якості життя вірогідно змінився лише показник рольового фрункціонування: у групі порівняння він став вірогідно меншим, як відносно вихідного стану, так і порівняно 3 основною групою. Аналіз результатів інтерв'ювання жінок із використанням опитувача FertiQoL у динаміці KCO показав, що відбулося покращення якості життя у ссрері емоцій в основній групі.

Висновок. Хоча в цілому якість життя в процесі лікування суттєво не змінилась, при використанні пролонгованого препарату для КСО терапія суб'єктивно пацієнтками переносилася краще.

Ключові слова: трубно-перитонеальне безпліддя; якість життя; контрольована стимуляція овуляції.

КАЧЕСТВО ЖИЗНИ ПАЦИЕНТОК С ТРУБНО-ПЕРИТОНЕАЛЬНЫМ БЕСПЛОДИЕМ В ПРОЦЕССЕ ЛЕЧЕНИЯ

Цель исследования - изучить качество жизни женщин репродуктивного возраста с трубно-перитонеальным бесплодием в процессе КСО.

Материалы и методы. Для решения поставленной цели проведено обследование 250 женщин репродуктивного возраста с трубно-перитонеальным бесплодием, которые были разделены на две группы и отличались лишь использованным препаратом для KCO. Оценку качества жизни проводили с использованием опросника «SF-36» и международной анкеты FertiQol (2008).

Результаты исследования и их обсуждение. Оценка качества жизни с помощью опросника «SF-36» показала, что до начала лечения бесплодия у женщин с трубно-перитонеальным бесплодием она была достаточно низкой, в первую очередь, за счет психологического компонента здоровья. Изучение качества жизни при использовании oпроcника FertiQoL показала, что больше всего страдало качество жизни у женщин с бесплодием в социальной ссрере. Повторный опрос пациенток с бесплодием проводился на 5 день после эмбриотрансфера. В фризическом компоненте качества жизни достоверно изменился лишь показатель ролевого фрункционирования: в группе сравнения он стал достоверно меньше, как относительно исходного состояния, так и по сравнению с основной группой. Анализ результатов интервьюирования женщин с использованием опросника FertiQoL в динамике KCO показал, что произошло улучшение качества жизни в сфрере эмоций в основной группе.

Вывод. Хотя в целом качество жизни в процессе лечения существенно не изменилось, при использовании пролонгированного препарата КСО терапия субъективно пациентками переносилась лучше.

Ключевые слова: трубно-перитонеальное бесплодие; качество жизни; контролируемая стимуляция овуляции.

QUALITY OF LIFE OF PATIENTS WITH TUBOPERITONEAL INFERTILITY DURING THE TREATMENT

The aim of the study - to learn the quality of life of reproductive age women with tubal-peritoneal infertility in the process of COS.

Materials and Methods. To achieve this goal, there was carried out a survey of 250 reproductive age women with tuboperitoneal infertility, who were divided into two groups and differed only by the used preparation for COS. The quality of life was assessed using the "SF 36" questionnaire and the "FertiQol" international questionnaire (2008).

Results and Discussion. Evaluation of the quality of life using the "SF 36" questionnaire showed that before the onset of infertility treatment in women with tuboperitoneal infertility it was rather low, primarily due to the psychological component of health. A study of the quality of life using the FertiQoL questionnaire showed that the social component of quality of life of women with sterility suffered most of all. Repeated survey of patients with infertility was conducted on day 5 after embryotransfer. Only the indicator of role functioning reliably changed in the physical component of the quality of life: in the comparison group it became significantly less, both in relation to the initial state and in comparison with the main group. Analysis of the results of interviewing women using the FertiQoL questionnaire in the dynamics of COS showed that there was an improvement in the quality of life in the field of emotions in the main group.

Conclusion. Although, in general, the quality of life did not change significantly in the dynamics of treatment, therapy when using the prolonged preparation for COS was subjectively tolerated by patients better.

Key words: tubal-peritoneal infertility; quality of life; controlled ovulation stimulation. 
ВСТУП. Народження дитини - одне з природних людських бажань, яке є обов'язковим для виживання людського виду. За оцінками, в усьому світі 72,4 мільйона пар мають первинне або вторинне безпліддя [1]. Показники безпліддя в різних країнах коливаються в межах 5-30 \% [2]. Причиною безплідного шлюбу в 40-50 \% випадків $\epsilon$ патологія репродуктивної системи в одного 3 партнерів, рідше - в 25-30 \% в обох [3]. Захворювання труб у структурі жіночого безпліддя складають від 29,5 до 83 \% [4] При первинному безплідді частота ураження маткових труб становить 29,5-70 \%, при вторинному - 42-83 \% [5]. Іншими словами, трубно-перитонеальна фрорма безпліддя є найбільш розповсюдженою причиною відсутності можливості в жінки завагітніти.

Безпліддя індукує численні психологічні, економічні, етичні та культурні наслідки, які призводять до зменшення впевненості в собі, та якість життя [6]. Само по собі та пов'язані з ним діагностичні або терапевтичні заходи, які включають фрармакологічне лікування (пероральне/парентеральное введення препаратів), внутрішньоматкове або екстракорпоральне запліднення накладають тяжкий тягар на постраждалі пари.

Відповідно до керівних принципів Всесвітньої організації охорони здоров'я (ВООЗ), «якість життя - це сприйняття індивідуумами своєї позиції в житті в контексті культурних та ціннісних систем, у яких вони живуть» [7]. Велика кількість досліджень присвячена вивченню якості життя безплідних пар. Згідно з літературою, безпліддя негативно впливає на якість життя і призводить до психологічних проблем, таких, як тривога, депресія, розчарування, ізоляція, порушення ідентичності та відсутність тяжіння [8-10]. У той же час майже не існує досліджень, які б вивчали якість життя жінок із безпліддям у процесі лікування та контрольованої стимуляції овуляції (КСО), а також її залежність від препаратів, які використовуються.

MEТА ДОСЛІДЖЕННЯ - вИвчити Якість ЖиттЯ Жінок репродуктивного віку з трубно-перитонеальним безпліддям у процесі їх лікування методом екстракорпорального запліднення в процесі КСО.

МАТЕРІАЛИ ТА МЕТОДИ. Для вирішення поставленої мети проведено обстеження 250 жінок репродуктивного віку з трубно-перитонеальним безпліддям. Жінки методом випадкової вибірки розподілені на дві групи: I (основну, $\mathrm{n=121}$ ) та II (порівняння, $\mathrm{n}=129$ ).

Критеріями включення в дослідження були: вік жінки від 18 до 35 років, наявність виключно трубно-перитонеального фактора безпліддя; відсутність чоловічого фрактора безпліддя; відсутність тяжких соматичних захворювань, які можуть впливати на результати стимуляції; відсутність патології ендометрія, яка може впливати на процеси імплантації ембріона; індекс маси тіла (IMT) $\geq$

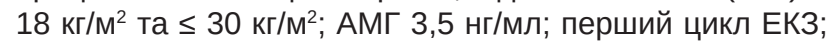
вага пацієнтки 60 кг та більше. Критерії виключення 3 дослідження були такі: відмова пацієнток від участі в дослідженні; відсутність комплаєнтності до призначенного лікування; виявлення при обстеженні гострих або підгострих форм запальних захворювань органів малого таза або ІПСШ (включення було можливе після протизапального лікування); синдром полікістозних яєчників; наявність протипоказань до використання будь-якого 3 препаратів, які використовуються в циклах стимуляції, або алергія на них; менше 4 та більше 15 антральних фололікулів.

Оцінку якості життя виконували з використанням опитувача «SF-36 Health Status Survey» [11]. «SF-36» відноситься до неспецифічних опитувачів для оцінки якості життя (ЯЖ), він широко поширений у США і країнах Європи при проведенні досліджень якості життя. 36 пунктів опитувача згруповані у вісім шкал: фрізичне фрункціонування, рольова діяльність, тілесний біль, загальне здоров'я, життєздатність, соціальне функціонування, емоційний стан і психічне здоров'я. Показники кожної шкали варіюють між 0 і 100, де 100 являє повне здоров'я, всі шкали формують два показники: душевне і фрізичне благополуччя [12]. Результати представляються у вигляді оцінок у балах за 8 шкалами, складених таким чином, що більш висока оцінка вказує на більш високий рівень ЯЖ. Кількісно оцінюються такі показники: фрізичне фрункціонування; рольове фрункціонування, обумовлене фрізичним станом; інтенсивність болю і його вплив на здатність займатися повсякденною діяльністю; загальний стан здоров'я; життєва активність; соціальне фрункціонування; рольове фрункціонування; психічне здоров'я. Шкали групуються у два показники «фізичний компонент здоров'я» та «психологічний компонент здоров'я».

Враховуючи те, що опитувач SF-36 не враховує деяких аспектів життя, психологічного стану і впливу лікування у жінок із безпліддям на соціальний стан, Європейським товариством репродукції людини та ембріології та Американським товариством репродуктивної медицини для визначення якості життя безплідних жінок розроблена міжнародна анкета «Фертильність та якість життя» (Fertility Quality of Life) (2008) [13]. Анкета оцінює, зокрема, вплив безпліддя на самооцінку, емоції, загальний стан здоров'я, стосунки у шлюбі та соціальні взаємовідносини, роботу та майбутні плани на життя. FertiQoL організовано таким чином: має два окремих елементи, які охоплюють загальну оцінку фрізичного здоров'я, решта 34 пункти структуровані як основний розділ, що стосується якості особистого та міжособистісного життя («Core FertiQol») та має додатковий розділ, що стосується якості лікування життя («Лікування FertiQol»).

«Лікування FertiQol» має десять позицій, які оцінюють якість життя під час лікування, що включає в себе будьяке медичне втручання або консультацію відповідно до умов лікування (6 пунктів) та переносимість лікування (4 пункти). Цей розділ розроблений для оцінки якості лікування та взаємодії з медичним персоналом, а також переносимості лікування, оцінює досвід психічних та орізичних симптомів та порушення щоденного життя внаслідок лікування.

Отже, на початку дослідження нами з вказаного опитувача було взято лише основний розділ, а після закінчення лікування - обидва.

Обробку даних проводили з використанням методів варіаційної статистики, Х2-критерію і точного критерію Фішера.

РЕЗУЛЬТАТИ ДОСЛІДЖЕННЯ ТА ЇХ ОБГОВОРЕНня. Оцінка якості життя за допомогою опитувача «SF-36 Health Status Survey» показала, що до початку лікування безпліддя в жінок із трубно-перитонеальним безпліддям вона суттєво не відрізнялася між групами та загалом була 
досить низькою й складала $(58,42 \pm 2,18)$ та $(54,47 \pm 1,85)$ бала (табл. 1, p>0,05).

Якість життя була низькою, в першу чергу, за рахунок психологічного компонента здоров'я $((33,72 \pm 2,34)$ бала в групі I та $(37,56 \pm 2,03)$ бала в групі II, p>0,05). Причому, якщо життєва активність перевищувала 50 балів

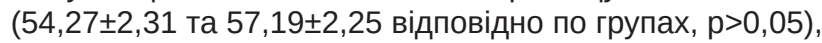
то оцінки за розділами соціального функціонування, емоційного компонента та психічного здоров'я складали

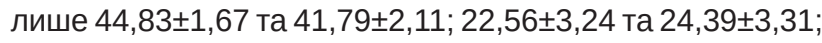

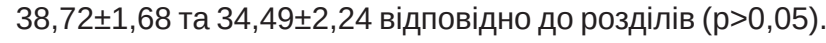
Треба відзначити, що найнижчі оцінки були за розділом емоційного фрункціонування, тобто наявність проблеми з фертильністю значно впливала на емоційний стан обстежених жінок.

Опитані пацієнтки мали досить високі оцінки за шкалами фрізичного функціонування $((75,43 \pm 3,15)$ та $(71,18 \pm 2,69)$ бала відповідно по групах, $p>0,05)$, загального стану здоров'я $((81,65 \pm 2,29)$ та $(84,21 \pm 1,97)$ бала, p>0,05) й інтенсивності болю $((86,37 \pm 3,25)$ та $(81,49 \pm 2,79)$ бала, p>0,05). Найнижча оцінка в розділі фрізичного компонента здоров'я була за шкалою рольового фрункціонування $((69,28 \pm 2,68)$ й $(65,83 \pm 3,15)$ бала відповідно, $р>0,05)$.

Таким чином, фрізичний компонент здоров'я в цілому склав $(77,34 \pm 3,16)$ та $(74,55 \pm 2,58)$ бала $(p>0,05)$. Отримані дані вказують на хороший загальний стан здоров'я опитаних жінок і відсутність негативного впливу його на загальну якість їх життя.
Отже, базова оцінка якості життя пацієнток із трубно-перитонеальним безпліддям показала її зниження за рахунок психологічного компонента здоров'я. Можна припустити, що наявність проблем із фертильністю впливає на психологічний стан жінок, а це відбивається на їх якості життя.

Анкета «Фертильність та якість життя» (Fertility Quality of Life) (2008) [13] оцінює вплив безпліддя на самооцінку, емоції, загальний стан здоров'я, стосунки у шлюбі та соціальні взаємовідносини, роботу та майбутні плани на життя. Опитування пацієнток проводилося до початку лікування та по закінченні циклу стимуляції КОС на п'ятий день після ембріотрансфреру.

Основна частина опитувача містить 4 групи питань. Окремо є два запитання: «Як Ви оцінюєте стан Вашого здоров'я?» та «Чи задоволені Ви якістю Вашого життя?». Більшість опитаних жінок оцінила своє здоров'я як «хороше» $(80,17$ \% та 71,32 \% відповідно по групах, p>0,05), a кожна п'ята - «не хороше/не погане» $(19,83 \%$ та 28,68\%, p>0,05). Жодна не відповіла - «погане», «дуже погане» або «дуже хороше». Тобто, в цілому, середній бал суб'єктивної оцінки стану свого здоров'я жінками з безпліддям склав

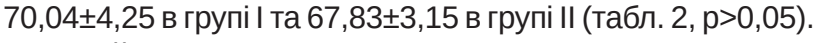

У той же час суб'єктивна задоволеність якістю життя в них була значно нижчою: $(40,50 \pm 1,25)$ та $(41,28 \pm 2,12)$ бала відповідно по групах ( $>>0,05)$. Значна частка жінок відповіла на запитання «щось середнє» $(61,98 \%$ та 65,12\%, p>0,05), а інша частина «незадоволена» (38,02\% та 34,88\%, p>0,05).

Таблиця 1. Загальна якість життя обстежених пацієнток із трубно-перитонеальним безпліддям у динаміці лікування

\begin{tabular}{|l|c|c|c|c||}
\hline \multirow{2}{*}{\multicolumn{1}{|c|}{ Показник }} & \multicolumn{2}{c|}{ Група I, $\mathrm{n}=121$} & \multicolumn{2}{c||}{ Група II, $\mathrm{n}=129$} \\
\cline { 2 - 5 } & до КСО & після КСО & до КСО & після КСО \\
\hline Фізичне функціонування & $75,43 \pm 3,15$ & $71,18 \pm 2,56$ & $71,18 \pm 2,69$ & $67,29 \pm 3,04$ \\
\hline Рольове функціонування & $69,28 \pm 2,68$ & $67,45 \pm 2,19^{2}$ & $65,83 \pm 2,15$ & $56,23 \pm 1,57^{1}$ \\
\hline Інтенсивність болю & $86,37 \pm 3,25$ & $82,61 \pm 2,83$ & $81,49 \pm 2,79$ & $79,55 \pm 2,43$ \\
\hline Загальний стан здоров'я & $81,65 \pm 2,29$ & $79,83 \pm 3,46$ & $84,21 \pm 1,97$ & $80,32 \pm 2,19$ \\
\hline Фізичний компонент здоров'я & $77,34 \pm 3,16$ & $74,18 \pm 2,59$ & $74,55 \pm 2,58$ & $70,32 \pm 2,46$ \\
\hline Життєва активність & $54,27 \pm 2,31$ & $57,33 \pm 3,12$ & $57,19 \pm 2,25$ & $59,106 \pm 3,42$ \\
\hline Соціальне фуункціонування & $44,83 \pm 1,67$ & $46,02 \pm 2,85$ & $41,79 \pm 2,11$ & $44,36 \pm 2,54$ \\
\hline Емоційне фуункціонування & $22,56 \pm 3,24$ & $41,35 \pm 2,67^{1}$ & $24,39 \pm 3,31$ & $38,25 \pm 2,26^{1}$ \\
\hline Психічне здоров'я & $38,72 \pm 1,68$ & $39,22 \pm 3,17$ & $34,49 \pm 2,24$ & $37,12 \pm 3,31$ \\
\hline Психологічний компонент здоров'я & $33,72 \pm 2,34$ & $45,86 \pm 2,59^{1}$ & $37,56 \pm 2,03$ & $44,61 \pm 2,42^{1}$ \\
\hline Якість життя & $58,42 \pm 2,18$ & $60,31 \pm 2,73$ & $54,47 \pm 1,85$ & $57,23 \pm 3,17$ \\
\hline \hline
\end{tabular}

Примітка. ${ }^{1}$ - різниця вірогідна відносно вихідного стану, $p<0,05 ;{ }^{2}$ - різниця вірогідна відносно групи II, $p<0,05$.

Таблиця 2. Показники якості життя обстежених пацієнток із трубно-перитонеальним безпліддям за FertiQoL у динаміці коС

\begin{tabular}{|l|c|c|c|c||}
\hline \multirow{2}{*}{\multicolumn{1}{|c|}{ Показник }} & \multicolumn{2}{c|}{ Група I, $\mathrm{n}=121$} & \multicolumn{2}{c|}{ Група II, $\mathrm{n}=129$} \\
\cline { 2 - 5 } & до КСО & після КСО & до КСО & після КСО \\
\hline Емоції & $50,05 \pm 2,07$ & $58,43 \pm 1,65^{1}$ & $54,17 \pm 2,10$ & $57,83 \pm 1,38$ \\
\hline Психічне та фрізичне здоров'я & $62,70 \pm 2,25$ & $66,81 \pm 1,28^{2}$ & $58,33 \pm 2,07$ & $54,71 \pm 1,29$ \\
\hline Стосунки & $62,50 \pm 2,45$ & $65,07 \pm 1,79$ & $66,70 \pm 2,54$ & $67,24 \pm 2,43$ \\
\hline Соціальна сфрера & $45,83 \pm 3,32$ & $48,51 \pm 3,45$ & $37,50 \pm 3,65$ & $42,47 \pm 3,16$ \\
\hline Якість життя в цілому & $56,25 \pm 2,75$ & $60,79 \pm 2,23$ & $54,17 \pm 3,15$ & $54,85 \pm 2,42$ \\
\hline \hline
\end{tabular}

Примітка. ${ }^{1}$ - різниця вірогідна відносно вихідного стану, $p<0,05 ;{ }^{2}$ - різниця вірогідна відносно групи II, $p<0,05$. 
Оцінка відповідей опитувача FertiQoL показала подібні відповіді. Якість життя в емоціональній сфрері склала $(50,05 \pm 2,07)$ та $(54,17 \pm 2,10)$ бала $(p>0,05)$. Треба відзначити, що найнижчі оцінки в даному розділі були на запитання «Чи роблять Вас дратівливою проблеми з фертильністю?». Більшість жінок відповіла, що вони їх дуже сильно дратують. Фізичне та психологічне здоров'я було оцінено опитаними досить високо, середній бал склав

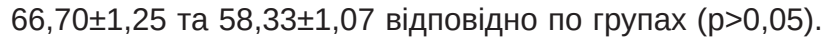
Найнижчі оцінки були на запитання «Чи відчуваєте Ви стомлення через проблеми з фертильністю?». Значна частка пацієнток відповіла «в деякій мірі».

Подібні результати були отримані на запитання щодо стосунків у парі $((62,50 \pm 2,45)$ та $(66,70 \pm 2,54)$ бала, p>0,05). Найнижчий бал отримано на запитання: «Чи важко Вам говорити з Вашим партнером про свої почуття у зв'язку з безпліддям?». Основна маса опитаних вважала, що їм важко обговорювати цю проблему з чоловіком (відповідь на запитання була «дуже сильно»).

Найбільше страждала якість життя в жінок із безпліддям у соціальній сорері. Середня оцінка була нижче 50 балів $(45,83 \pm 3,32$ та 37,5 $\pm 3,65, p>0,05)$. Вони вважали, що сім'я не розуміє, що вони відчувають та відчували тиск оточення щодо необхідності народити дитину.

Отже, загальна оцінка якості життя в жінок із трубноперитонеальним безпліддям виявилася досить низькою і склала $(56,25 \pm 2,75)$ та $(54,17 \pm 3,15)$ бала відповідно по групах ( $>>0,05)$.

Таким чином, оцінка якості життя при використанні опитувачів SF-36 та FertiQoL виявилась подібною, але за другим опитувачем вона була дещо нижчою.

Повторне опитування пацієнток із безпліддям проводилося на 5 день після ембріотранссреру. Треба відзначити, що оцінки опитувача SF-36 за всіма шкалами розділу фрізичного здоров'я дещо знизились (табл. 3), але за розділами фрізичного функціонування $(3(75,43 \pm 3,15)$ до $(71,18 \pm 2,56)$ та $3(71,18 \pm 2,69)$ до $(67,29 \pm 3,04)$ бала відповідно у групах I та II), інтенсивності болю (3 $(86,37 \pm 3,25)$ до $(82,61 \pm 2,83)$ та $3(81,49 \pm 2,79)$ до $(79,55 \pm 2,43)$ бала) i загального стану здоров'я (3 $(81,65 \pm 2,29)$ до $(79,83 \pm 3,46)$ та $3(84,21 \pm 1,97)$ до $(70,32 \pm 2,46)$ бала) це зниження було несуттєвим ( $>0,05)$. Тоді як показник рольового фрункціонування у групі порівняння став вірогідно меншим $((56,23 \pm 1,57)$ бала), як відносно вихідного стану $((65,83 \pm 2,15)$ бала), так і порівняно 3 основною групою $((67,45 \pm 2,19)$ бала, $p<0,05)$. Хоча в цілому фрізичний компонент здоров'я залишився зіставним як у динаміці, так і між групами $(p>0,05)$.

щодо психологічного компонента здоров'я відбулися протилежні зміни. А саме: зареєстровано тенденцію до підвищення оцінок за всіма шкалами, але за шкалами життєвої активності, соціального фрункціонування та психічного здоров'я це підвищення не було вірогідним ( $>0,05)$. Тоді як за розділом емоційного фрункціонування відбулося майже двократне підвищення оцінок (3 $(22,56 \pm 3,24)$ до $(41,35 \pm 2,67)$ бала та $3(24,39 \pm 3,31)$ до
$(38,25 \pm 2,26)$ бала відповідно у групах I та II, p<0,05). Треба відзначити, що статистично значущої різниці між показниками в основній та групі порівняння не зареєстровано ( $>>0,05)$. Це дає змогу припустити, що покращення емоційного стану відбулося за рахунок лікування як такого. Як результат вказаних змін відмічено покращення психологічного компонента якості життя в обох обстежених групах $3(33,72 \pm 2,34)$ до $(45,86 \pm 2,59)$ бала та $3(37,56 \pm 2,03)$ до $(44,61 \pm 2,42)$ бала відповідно $(p<0,05)$.

Незважаючи на поліпшення психологічної складової, якість життя пацієнток з трубно-перитонеальним безпліддям у динаміці КОС у цілому не змінилась, хоча відмічено незначне її покращення $3(58,42 \pm 2,18)$ до $(60,31 \pm 2,73)$ бала та $3(54,47 \pm 1,85)$ до $(57,23 \pm 3,17)$ бала відповідно по групах $(p>0,05)$.

Аналіз результатів інтерв'ювання жінок із використанням опитувача FertiQoL у динаміці KCO (табл. 4) показав, що, хоча в цілому якість життя не змінилась $((56,25 \pm 2,75)$ бала до КСО та $(60,79 \pm 2,23)$ бала - після в І групі, й $54,17 \pm 3,15$ та 54,85 $\pm 2,42$ - в II, p>0,05), але відбулися вірогідні зміни за деякими шкалами.

Так, відбулося покращення якості життя у ссрері емоцій в обох групах $(3(50,05 \pm 2,07)$ до $(58,43 \pm 1,65)$ бала та $3(54,17 \pm 2,10)$ до $(57,83 \pm 1,38)$ бала відповідно у групах I та II), але вірогідним воно виявилося лише в основній групі $(p<0,05)$, тоді як статистично значущої різниці між обстеженими групами після КСО не зареєстровано ( $p>0,05)$. Цікаві результати отримані за розділом психічного та орізичного здоров'я, а саме: в основній групі зареєстровано незначне збільшення оцінки за вказаним розділом (3 $(62,70 \pm 2,25)$ до $(66,81 \pm 1,28)$ бала, $p>0,05)$, тоді як у групі порівняння вона не вірогідно зменшилася $(3(58,33 \pm 2,07)$ до $(54,71 \pm 1,29)$ бала, p>0,05). Вказані зміни призвели до того, що показники за розділом психічного та фрізичного здоров'я між групами після КСО стали статистично значуще відрізнятися $(p<0,05)$.

У соціальній сорері та стосунках між партнерами істотних змін не відбулося ( $>0,05)$, хоча відмічена тенденція до збільшення оцінок за цими показниками (з $(45,83 \pm 3,32)$ до $(48,51 \pm 3,45)$ бала в соціальній сорері в групі I та $3(37,50 \pm 3,65)$ до $(41,47 \pm 3,16)$ бала - в групі II; $3(62,50 \pm 2,45)$ до $(65,07 \pm 1,79)$ бала у сорері стосунків у групі I та $3(66,70 \pm 2,54)$ до $(67,24 \pm 2,43)$ бала - в групі II).

Висновки. Аналіз якості життя пацієнток із трубноперитонеальним безпліддям показав, що вона в цілому в них досить низька, але в процесі лікування відбувається її покращення в емоційній сфері, але в жінок, яким для стимуляції овуляції використовувалися щодобові ін'єкції препаратів, відмічається погіршення рольового фрункціонування. Тобто, хоча в цілому якість життя в процесі лікування суттєво не змінилась, при використанні пролонгованого препарату для КСО терапія суб'єктивно пацієнтками переноситься краще.

ПЕРСПЕКТИВИ ПОДАЛЬШИХ ДОСЛІДЖЕНЬ. ПрОведене дослідження показало необхідність більш детального вивчення переносимості контрольованої стимуляції суперовуляції при використанні різних препаратів. 


\section{СПИСОК ЛІТЕРАТУРИ}

1. International estimates of infertility prevalence and treatment-seeking: potential need and demand for infertility medical care/ J. Boivin, L. Bunting, J. A. Collins, K. G. Nygren// Hum Reprod. - 2007. - Vol. 22 (6). - P. 1506-1512.

2. Larsen U. Primary and secondary infertility in sub-Saharan Africa / U. Larsen // Int. J. Epidemiol. - 2000. - Vol. 29 (2). -P. 285-291.

3. Авраменко Н. В. Вспомогательные репродуктивные технологии / Н. В. Авраменко // Запорожский медицинский журнал. - 2014. - № 3 (84). - С. 95-100.

4. Клиническая практика в репродуктивной медицине : руководство для врачей / под ред. В. Н. Локшина, Т. М. Джусубалиевой. - Алматы : MedMedia Казахстан, 2015. - 464 с.

5. Гинекология : учебник / под ред. В. Е. Радзинского, А. М. Фукса. - М. : ГЭОТАР Медиа, 2014. - 1000 с.

6. Forouhari S. A survey of psychosexual disorders in infertile women referred to the Zeinabiee Infertility Center of Shiraz University of Medical Sciences / S. Forouhari, S. Z. Ghaemi // Res. J. Biol. Sci. - 2013. - Vol. 8 (4). - P. 99-103.

7. Impact of infertility on quality of life, marital adjustment, and sexual function / M. Monga, B. Alexandrescu, S. E. Katz [et al.] // Urology. - 2004. - Vol. 63 (1). - P. 126-130.

\section{REFERENCES}

1. Boivin, J., Bunting, L., Collins, J.A., \& Nygren, K.G. (2007). International estimates of infertility prevalence and treatmentseeking: potential need and demand for infertility medical care. Hum. Reprod., 22 (6), 1506-1512.

2. Larsen, U. (2000). Primary and secondary infertility in sub-Saharan Africa. Int. J. Epidemiol., 29 (2), 285-291.

3. Avramenko, N.V. (2014). Vspomogatelnyye reproduktivnyye tekhnologii [Assisted reproductive technologies]. Zaporozhskiy meditsinskiy zhurnal - Zaporozhye Medical Journal, 3 (84), 95-100 [in Russian].

4. Lokshin, V.N., \& Dzhusubaliyeva, T.M. (Eds.). (2015). Klinicheskaya praktika $v$ reproduktivnoy meditsine: rukovodstvo dlya vrachey [Clinical practice in reproductive medicine: a guide for doctors]. Almaty: MedMedia Kazakhstan [in Russian].

5. Radzinskiy, V.Ye., \& Fuks, A.M. (Eds.). (2014). Ginekologiya: uchebnik [Gynecology: a textbook]. Moscow: GEOTAR Media [in Russian].

6. Forouhari, S., \& Ghaemi, S.Z. (2013). A survey of psychosexual disorders in infertile women referred to the Zeinabiee Infertility Center of Shiraz University of Medical Sciences. Res. J. Biol. Sci., 8 (4), 99-103.

7. Monga, M., Alexandrescu, B., Katz, S.E., Stein, M., \& Ganiats, T. (2004). Impact of infertility on quality of life, marital adjustment, and sexual function. Urology, 63 (1), 126-130.
8. Jun Chi H. Psychological distress and fertility quality of life (FertiQoL) in infertile Korean women: The first validation study of Korean FertiQoL / Chi H. Jun, I. H. Park, H. G. Sun [et al.] // Clin. Exp. Reprod. Med. - 2016. - Vol. 43 (3). - P.174-180.

9. Quality of life and its related factors in infertile couples / A. Keramat, S. Z. Masoomi, S. A. Mousavi // J. Res. Health Sci. - 2014. - Vol. 14 (1). P. 57-63.

10. A survey of relationship between anxiety, depression and duration of infertility / F. Ramezanzadeh, M.M. Aghssa, N. Abedinia [et al.] // BMC Womens Health. - 2004. - Vol. 4 (1). - P. 9.

11. SF-36 Health Survey. Manual and interpretation guide / J. E. Ware, K. K. Snow, M. Kosinski, B. Gandek // The Health Institute, New England Medical Center. - Boston, Mass. - 1993.

12. Исследование качества жизни и психологического статуса больных с хронической сердечной недостаточностью / А. О. Недошивин, А. Э. Кутузова, Н.Н.Петрова [и др.] // Сердечная недостаточность. - 2000. - Т. 1, № 4. - С. 45-51.

13. Boivin J. The fertility quality of life (FertiQoL) tool: development and general psychometric properties / J. Boivin, J. Takefman, A. Braverman // Human Reproduction. - 2011. Vol. 26, No. 8. - P. 2084-2091.

8. Jun Chi, H., Park, I.H., Sun, H.G., Kim, J.W., \& Lee, K.H. (2016). Psychological distress and fertility quality of life (FertiQoL) in infertile Korean women: The first validation study of Korean FertiQoL. Clin. Exp. Reprod. Med., 43 (3), 174-180.

9. Keramat, A., Masoomi, S.Z., Mousavi, S.A., Poorolajal, J., Shobeiri, F., \& Hazavhei, S.M. (2014). Quality of life and its related factors in infertile couples. J. Res. Health Sci., 14 (1), 57-63.

10. Ramezanzadeh, F., Aghssa, M.M., Abedinia, N., Zayeri, F., Khanafshar, N., Shariat, M., et al. A survey of relationship between anxiety, depression and duration of infertility. BMC Womens Health, 4 (1), 9.

11. Ware, J.E., Snow, K.K., Kosinski, M., \& Gandek, B. (1993). SF-36 Health Survey. Manual and interpretation guide. The Health Institute, New England Medical Center. Boston, Mass.

12. Nedoshivin, A.O., Kutuzova, A.E., Petrova, N.N., Varshavskiy, S.Yu., \& Perepech, N.B. (2000). Issledovaniye kachestva zhizni i psikhologicheskogo statusa bolnykh s khronicheskoy serdechnoy nedostatochnostyu [Study of the quality of life and psychological status of patients with chronic heart failure]. Serdechnaya nedostatochnost - Heart Failure, 1 (4), 45-51 [in Russian].

13. Boivin, J., Takefman, J., \& Braverman, A. (2011). The fertility quality of life (FertiQoL) tool: development and general psychometric properties. Human Reproduction, 26 (8), 20842091. 